\title{
BIOCHEMICAL ANALYSIS ON CROP SHOOTS OF CAMELLIA SINENSIS (L.) O. KUNTZE TEA FROM THE SELECTED UPASI-16 CLONE
}

\author{
${ }^{1}$ Ramkumar Samynathan', Chella Perumal Palanisamy ${ }^{2}$, Sudhakar Gandhi', \\ Abdul Kalam A. Mandal ${ }^{4}$, Mohankumar Padmanabhan ${ }^{4}$, Suresh Kumar Perisamy ${ }^{3}$, \\ Gopalakrishnan Velliyur Kanniappan ${ }^{2}$ \\ ${ }^{1}$ Department of Biochemistry, Karpagam University, Coimbatore, India \\ ${ }^{2}$ Cancer Biology and Medicinal Chemistry Unit, Dept of Biochemistry and Bioinformatics, \\ Karpagam University, Coimbatore, India \\ ${ }^{3}$ Department of Biotechnology, Anna University, BIT campus, Trichirappalli \\ ${ }^{4}$ Plant Physiology \& Biotechnology Division, UPASI Tea Research Foundation, \\ UPASI Tea Research Institute, Nirar Dam BPO, Coimbatore, India
}

\begin{abstract}
Commercial tea comes from plants belonging to a relatively large group of cultivated species of Camellia sinensis (L) 0 . Kuntze. It is one of the oldest known beverages made from the tender leaves of the plants. The main aim of the present study is to analyze the presence of biochemicals in UPASI -16 clone. In the results, the UPASI -16 clone showed high catechin (22.88\%), polyphenol (31.70\%), polyphenol oxidase (1178.63 $\mathrm{U} / \mathrm{mg}$ of protein) and tea enzyme peroxidase $\left(729.72 \mu \mathrm{M}\right.$ of $\mathrm{O}_{2}$ formed $\mathrm{min}^{-1} \mathrm{~g}^{-1}$ dry weight), catalase (1.89 $\mu \mathrm{M} \mathrm{H}_{2} \mathrm{O}_{2}$ reduced $\mathrm{min}^{-1} \mathrm{mg}^{-1}$ protein) and Super oxide dismutase $(58.45 \mathrm{U} / \mathrm{mg}$ proteins). UPASI -16 showed high catechin content in segregated tea crop shoots from the first internodes (23.66\%) followed by the first leaf $(22.46 \%)$, second leaf and third leaf. Tea quality flavonoid gene expression, while ANR (1.66\%) and F3H $(1.02 \%)$ were down regulated, $\mathrm{F} 35 \mathrm{H}$ and ANS $(2.82 \%)$ were up regulated in UPASI -16 . Based on the results, it can be concluded that crop shoots of Camellia sinensis (L) 0. Kuntze selected clone of UPASI-16 may possess high amount of biochemicals and may further lead to development of commercial tea.
\end{abstract}

Keywords: Camellia sinensis (L) O. Kuntze, UPASI -16 clone, biochemical analysis, gene expression analysis

Address for correspondence:
Dr. Ramkumar Samynathan,
Department of Biochemistry
Karpagam University
Coimbatore 641021
Tamil Nadu, India
Tel: 091-0422-6453777
Fax: 091-0422-2611043
e-mail: ramkumarbiochem007@gmail.com

Received: February 12, 2015

Accepted: May 25, 2015

\section{INTRODUCTION}

Tea is an important economic crop in many Asian and African countries. In India tea is one of the major plantation crops (planted on an area of 5 , 20,000 ha) and has been accepted as a healthy drink for all ages (1). Tea plantation is an agro-based, ecofriendly, labour intensive, employment generating and export oriented industry in our country $(2,3)$. Presently, tea industry occupies significant position and plays a paramount role in the national economy and our country is the second largest producer of 
Ramkumar Samynathan, Chella Perumal Palanisamy, Sudhakar Gandhi et al.

black tea. Black tea is most preferred due to its exquisite aroma and astringency $(4,5)$. Natural substances which are presented in the plant help the treatment of cardiovascular diseases. They also have anti-microbial, anti-allergic activity and, especially in cancer prevention, their impact has been very well investigated (6-11). The tea crop shoots (apical bud and two terminal leaves) are harvested for tea manufacturing. Two types of tea are manufactured in India viz., CTC (crush, tear and curl) and orthodox, depending on the time of the fermentation. The nature of plucked tea leaves has the desired biochemical characteristic which in turn influences the quality of the black tea. The tea crop shoots possess many biochemical constituents namely, phenolic components, alkaloids, vitamins, enzymes, crude fiber, proteins, lipids and carbohydrates $(12,13)$.

The tea plant Camellia sinensis (L.) (family Theaceae) is grown in about 30 countries worldwide. It grows best in tropical and subtropical areas with adequate rainfall, good drainage, and slightly acidic soil. Tea is often planted in the highlands. In India and Sri Lanka, it is cultivated at elevations up to 2000 $\mathrm{m}$. In plantations, tea is planted at a density of 500010,000 plants per hectare and maintained as low shrubs of $1-1.5 \mathrm{~m}$ in height through regular pruning during harvesting. Manual plucking of the terminal bud and two youngest leaves yields the finest quality of tea, but the high cost of labour in some countries makes mechanical harvesting an economic necessity. Fresh tea leaves are very rich in catechins, which may constitute up to $30 \%$ of dry weight (14). Principal catechins of young tea leaves are epigallocatechin gallate (EGCG), epigallocatechin (EGC), epicatechin gallate (ECG), gallocatechin (GC), epicatechin (EC) and catechin. Content of catechins varies with climate, season, horticultural practices, leaf age and variety (15).

Therefore, in this study, we aimed to analyze biochemical characteristics, quality important enzymes, HPLC fraction analysis of catechin and flavonoid related gene expression from Camellia sinensis (L) O. Kuntze selected UPASI-16 clone crop shoot (bud, first Internode, first Leaf and second Leaf) consisting of an apical bud and two terminal leaves.

MATERIALS AND METHODS

Collection of plant material and extract preparation
UPASI-16 clone crop shoots (apical bud and two terminal leaves) from plants of uniform age ( 10 years old) maintained at the height of $26 "(\sim 60 \mathrm{~cm})$ above ground level were selected. Young tea leaves were collected during the morning hour from 8.30 am to 9.00 am and the crop shoots (100 mg each) were ground well with $5 \mathrm{ml}$ of ethyl alcohol and made up to $50 \mathrm{ml}$ for biochemical and molecular analyses.

\section{Biochemical analyses}

Estimation of PPO activity

Polyphenol oxidases (PPO) are copper containing proteins that catalyse the aerobic oxidation of phenolic substrates to quinines, which are autooxidized to dark brown pigments known as melanins. These can be estimated spectrophotometrically at $495 \mathrm{~nm}$.

PPO was estimated from freshly collected crop shoots following the method described by Bradford (1979) (16). Bound and soluble form of PPO was estimated separately from which total PPO was computed. The activity was expressed in U/mg of protein. Protein content was determined according to the coomassie blue binding method of Bradford.

Estimation of total polyphenols concentration

One $\mathrm{ml}$ of the alcoholic extract was diluted to 50 $\mathrm{ml}$ with distilled water. Two $\mathrm{ml}$ of diluted extract was added with $4.0 \mathrm{ml}$ of Folin-Ciocalteu's reagent (1:1) and $2.0 \mathrm{ml}$ of $35 \%$ sodium carbonate. The contents were further made up to $10.0 \mathrm{ml}$ with distilled water and the mixture was shaken thoroughly and allowed to stand still for 30 minutes. Absorbance of the blue color developed and was read at $700 \mathrm{~nm}$ against the reagent blank using PerkinElmer Lambda-35 UVVisible spectrophotometer. Quantum of polyphenols present in tea leaves was computed using the standard calibration curve derived from known concentrations (10 to $50 \mathrm{ppm}$ ) of gallic acid (Sigma Chemicals Private Limited, Bangalore) and the results were expressed as per cent gallic acid equivalents (Dev Choudhury and Goswami, 1983) (17).

\section{Estimation of catechins concentration}

One $\mathrm{ml}$ of the alcoholic extract was diluted to $50 \mathrm{ml}$ with distilled water. To the $2.0 \mathrm{ml}$ of the diluted extract, $6.5 \mathrm{ml}$ of ice cold vanillin (1\% vanillin in $70 \%$ sulphuric acid) was added slowly to avoid immediate colour development. The contents were made up to $10 \mathrm{ml}$ with distilled water, shaken well 
Biochemical analysis on crop shoots of camellia sinensis (1.) O. Kuntze tea from the selected upasi-16 clone

and allowed to stand still for 15 minutes for completion of the reaction. Absorbance of the orange colour developed and was read at $500 \mathrm{~nm}$ against the reagent blank in PerkinElmer Lambda-35 UV-Visible spectrophotometer. Amount of catechins present in tea leaves were calculated using the standard calibration curve computed with the values obtained against known concentrations (10 to $50 \mathrm{ppm}$ ) of (+) catechin (Sigma Chemicals Private Limited, Bangalore) and the results were expressed as per cent catechin equivalents (Swain and Hillis, 1959).

\section{Catechin fraction analysis by HPLC}

The segregated parts of the crop shoots were weighed and dried in a hot air oven maintained at $70^{\circ} \mathrm{C}$ for 48 hour. Weighed dry leaves were ground well and passed through 30 minutes mesh sieve and used for the analysis of catechin fractions.

Oven dried leaf powder $(0.2 \mathrm{~g})$ was extracted using $10.0 \mathrm{ml}$ of $70 \%$ methanol on a water bath maintained at $70^{\circ} \mathrm{C}$ for $10 \mathrm{~min}$. One $\mathrm{ml}$ of the extract was diluted to $5.0 \mathrm{ml}$ with stabilizing solution $(0.25 \%$ each of EDTA and ascorbic acid in $10.0 \%$ acetonitrile) according to ISO/CD 14502-2 (International Standard Organization/Committee Draft Number). The sample was filtered through $0.45 \mu \mathrm{m}$ nylon membrane filter (Millipore, USA) and used for HPLC analysis using Hewlett Packard Model 1100 Series, USA fitted with $5 \mu \mathrm{m}$ Luna Phenyl-Hexyl bonded column (Phenomenex, USA).

Acetic acid (2.0\%) and acetonitrile (9.0\%) was used as mobile phase A and acetonitrile (80\%) as mobile phase B. The gradient programme was as follows: $100 \%$ mobile phase A for 10 minutes, followed by $68 \%$ mobile phase $\mathrm{A}$ for 15 minutes and a linear gradient of $32 \%$ mobile phase B and a hold at this condition for 10 minutes. The conditions were then reset to $100 \%$ mobile phase $\mathrm{A}$ and allowed to equilibrate for 10 minutes before the next injection (Jibu thomas et al., 2005). Absorbance was measured at $278 \mathrm{~nm}$. The reference standards (GA, epigallo catechin, (+) catechin, epicatechin, epigallo catechin gallate, caffeine and epicatechin gallate) were procured from Sigma-Aldrich (St Louis, MI, USA) and used in spiking tests. Based on the curve integration, the data processing was performed using HP Chem station software (Hewlett Packard, USA)

\section{Estimation of peroxidase activity}

Determination of peroxidase activity was carried out on fresh tea leaves by following the method described by Chance and Maehly (19). Peroxidase activity was estimated spectrophotometrically at 430 $\mathrm{nm}$ and expressed in $\mu$ mole of $\mathrm{O}_{2}$ formed min $^{-1} \mathrm{~g}^{-1}$ dry weight. One unit ( $\mu$ mole oxygen formed per minute per gram dry weight) of peroxidase will form $1 \mathrm{mg}$ of purpurogallin from pyrogallol in 20 seconds.

\section{Estimation of catalase activity}

Catalase activity was determined on fresh tea leaves following the method of Luck (20). The activity of catalase was determined spectrophotometrically at $420 \mathrm{~nm}$ and expressed as $\mu \mathrm{mol}$ of $\mathrm{H}_{2} \mathrm{O}_{2}$ reduced $\mathrm{min}^{-1} \mathrm{mg}^{-1}$ protein.

\section{Estimation of super oxide dismutase activity}

Estimation of super oxide dismutase (SOD) activity was estimated in fresh tea leaves by following the modified method of Van Rossun (21). The assay reaction was carried out at $25^{\circ} \mathrm{C}$ and under light and dark conditions. The increase in absorbance at 620 $\mathrm{nm}$ due to the blue color formation by NBT photo reduction was measured. The reaction mixtures without tissue supernatant were used as control. The SOD activity was expressed as U/mg of protein. One unit of SOD is defined as the amount of protein that reduces 50\% inhibition of NBT reduction.

\section{Estimation of Phenylalanine ammonia lyase}

In the estimation of Phenylalanine ammonia lyase (PAL) activity, the segregated two leaves and the bud (5 gm each) were homogenized with $80 \%$ ice cold aqueous acetone and the suspension was filtered on sintered funnel (Grade-1). The residue was washed repeatedly 3-4 times with ice cold acetone until the powder became colourless. PAL activity was determined by using $0.05 \mathrm{M}$ of phenylalanine as substrate by following the modified methods of Jain (22). Absorbance was read at $273 \mathrm{~nm}$ using UV-Vis spectrophotometer and one unit of enzyme activity is expressed as mmole of cinnamic acid formed per minute per gram of acetone powder.

\section{Protein profile in crop shoots by SDS-PAGE}

The molecular weight of the partially purified PPO was estimated by SDS-PAGE electrophoresis and was determined according to the method of Laemmli, 1970. The protein was analyzed by SDSPAGE using $12 \%$ polyacrylamide gel, and visualized 
Ramkumar Samynathan, Chella Perumal Palanisamy, Sudhakar Gandhi et al.

with Coomassie Blue R-250 staining, and molecular weights were estimated by comparison with the molecular weight markers and Genetool, Syngene: (V.4.01) was used. The protein profile (number and intensity of bands were observed in this work). Electrophoresis was carried out with $1 \mathrm{X}$ Tris-glycine buffer at $30 \mathrm{~mA}$ for 3 hours. The gel was stained overnight in CBB-R250 staining solution (0.1\% Comassie Brilliant Blue (AR), 50\% methanol and 10\% acetic acid) and destained in a solution of $12 \%$ methanol and $7 \%$ acetic acid.

Flavonoid gene expression by Semi-quantitative RT-PCR

The total RNA extracted from RNeasy Plant Mini Kit (QIAGEN, USA), the segregated two leaves and an apical bud of UPASI -16 and P/11/15, were treated with RNAs- free DNAase I (TaKaRa). DNA free total RNA (100 ng) was used in cDNA synthesis in a reaction volume of $10 \mu$ containing 2.5 units of AMV reverse transcriptase XL (Takara, Japan) and $1 \mathrm{mM}$ of oligo-dt3sap. The PCR reaction mixture contained $1.0 \mathrm{ml}$ of template, $2.5 \mathrm{ml}$ of $10 \mathrm{X}$ buffer, 0.5 units of Taq polymerase (Fermentas), $1.5 \mathrm{ml}$ of $2.5 \mathrm{mM} \mathrm{MgCl}_{2}, 1.0 \mathrm{ml}$ of $2.0 \mathrm{mM} \mathrm{dNTP}$ and $0.1 \mathrm{mM}$ of $1 \mathrm{ml}$ gene specific primers. The Gene specific primers used were Anthocyanidin synthase (ANS) - 5' ATGACTACAGTGGCTGCCCCGAGAG-3'; 5'-CTGAGCAAAAGTCCTCGGCGGGAA-3', Flavanone3' hydroxylase (F35H)-5'TAGACACCCGTCTTCCTGCTTCGT-3'; 5'GCAG-
CATAAGCATTGGAGGCAACC-3'), Flavanone3' 5' hydroxylase (F3H) -5'ATGGCGCCACAACGCTTAC-3'; 5'TCAAGCAAAAATCTCATCAGTC3' and Anthocyanidin reductase (ANR) -5'ATGGAAGCCCAACCGACAGCTC-3'; 5'-TCAATTCTTCAAAATCCCCTTAGCCT-3'. PCR amplification was performed in PTC - 200 thermal cycler (MJ Research, USA) using the following program: initial denaturation at $94^{\circ} \mathrm{C}$ for 2 minutes, followed by $94^{\circ} \mathrm{C}$ for 1 minute and $72^{\circ} \mathrm{C}$ for 1 minute with a final extension at $72^{\circ} \mathrm{C}$ for 5 minutes. The cycle conditions and annealing temperature varied viz., 33 cycles of $58^{\circ} \mathrm{C}$ for 45 seconds (ANS), 27 cycles of $62^{\circ} \mathrm{C}$ for 45 seconds $(\mathrm{F} 35 \mathrm{H}), 33$ cycles of $63^{\circ} \mathrm{C}$ for 45 seconds (F3H) and 33 cycles of $63^{\circ} \mathrm{C}$ for 45 seconds (ANR) respectively.

The PCR products were loaded on 1.5\% agarose gel, stained with ethidium bromide and visualized under the UV-Transilluminator (Hoefer, Inc, U.S.A) and documented. Reverse and forward primers of Camellia sinensis 26S rRNA (Cs26SrRNA, GenBank accession no. AY283368) were used as internal control. The semi-quantitative PCR assay was performed and analyzed at least twice. The intensity of bands was quantified using Image J software (http://rsb.info. nih.gov/ij) and normalized against Cs26SrRNA band intensity. The average expression ratio of the target gene was calculated between the normalized relative intensity of the band in the low and high PPO from two independent RT-PCR reactions.

Table 1. Distribution of enzymes and substrates in UPASI-16 clone

\begin{tabular}{|c|c|c|c|c|c|c|c|}
\hline $\begin{array}{l}\text { Biochemical } \\
\text { parameter }\end{array}$ & Bud & First leaf & $\begin{array}{c}\text { First } \\
\text { internode }\end{array}$ & $\begin{array}{l}\text { Second } \\
\text { leaf } \\
+ \text { Bud }\end{array}$ & $\begin{array}{l}\text { Third leaf } \\
+ \text { Bud }\end{array}$ & $\mathrm{SEM} \pm$ & $\begin{array}{c}\text { C.D. @ P } \\
=0.05\end{array}$ \\
\hline $\begin{array}{l}\text { Polyphenol } \\
\text { Oxidase }^{\mathrm{a}}\end{array}$ & 895.98 & 1172.81 & 1178.63 & 1106.38 & 797.01 & 36.11 & 80.45 \\
\hline Peroxidase $^{\mathrm{b}}$ & 727.00 & 695.83 & 729.72 & 516.85 & 421.74 & 21.68 & 48.32 \\
\hline $\begin{array}{l}\text { Superoxidase } \\
\text { dimutasec }\end{array}$ & 51.93 & 49.84 & 58.45 & 45.11 & 39.44 & 4.14 & 9.23 \\
\hline $\begin{array}{l}\text { Phenylalanine } \\
\text { ammonia lyase }\end{array}$ & 38.40 & 27.41 & 18.35 & 18.75 & 13.85 & 0.65 & 1.45 \\
\hline Catelase $^{\mathrm{e}}$ & 1.78 & 1.74 & 1.89 & 1.38 & 0.99 & 0.32 & 0.72 \\
\hline Polyphenols & 30.29 & 31.19 & 31.70 & 31.09 & 27.38 & 0.47 & 1.05 \\
\hline Catechin & 17.57 & 22.37 & 22.88 & 21.37 & 15.87 & 0.46 & 1.02 \\
\hline
\end{tabular}

$\boldsymbol{a}$-U/mg of protein, $\boldsymbol{b}$ - $\mu$ mole of $\mathrm{O} 2$ formed min-1g-1 dry weight, $\boldsymbol{c}-U / \mathrm{mg}$ of protein, $\boldsymbol{d}$ - $\mu$ mole of cinnamic acid formed min -1 g-1 acetone powder, $\boldsymbol{e}-\mu \mathrm{mol} \mathrm{H} 2 \mathrm{O} 2$ reduced min-1 mg-1 protein, Polyphenol, catechin in percentage.

Each value is the mean of triplicate. SEM-Standard Error Mean. C.D.-Critical difference 
Biochemical analysis on crop shoots of camellia sinensis (1.) O. Kuntze tea from the selected upasi-16 clone

Statistical analysis

The experiments were carried out in triplicate.
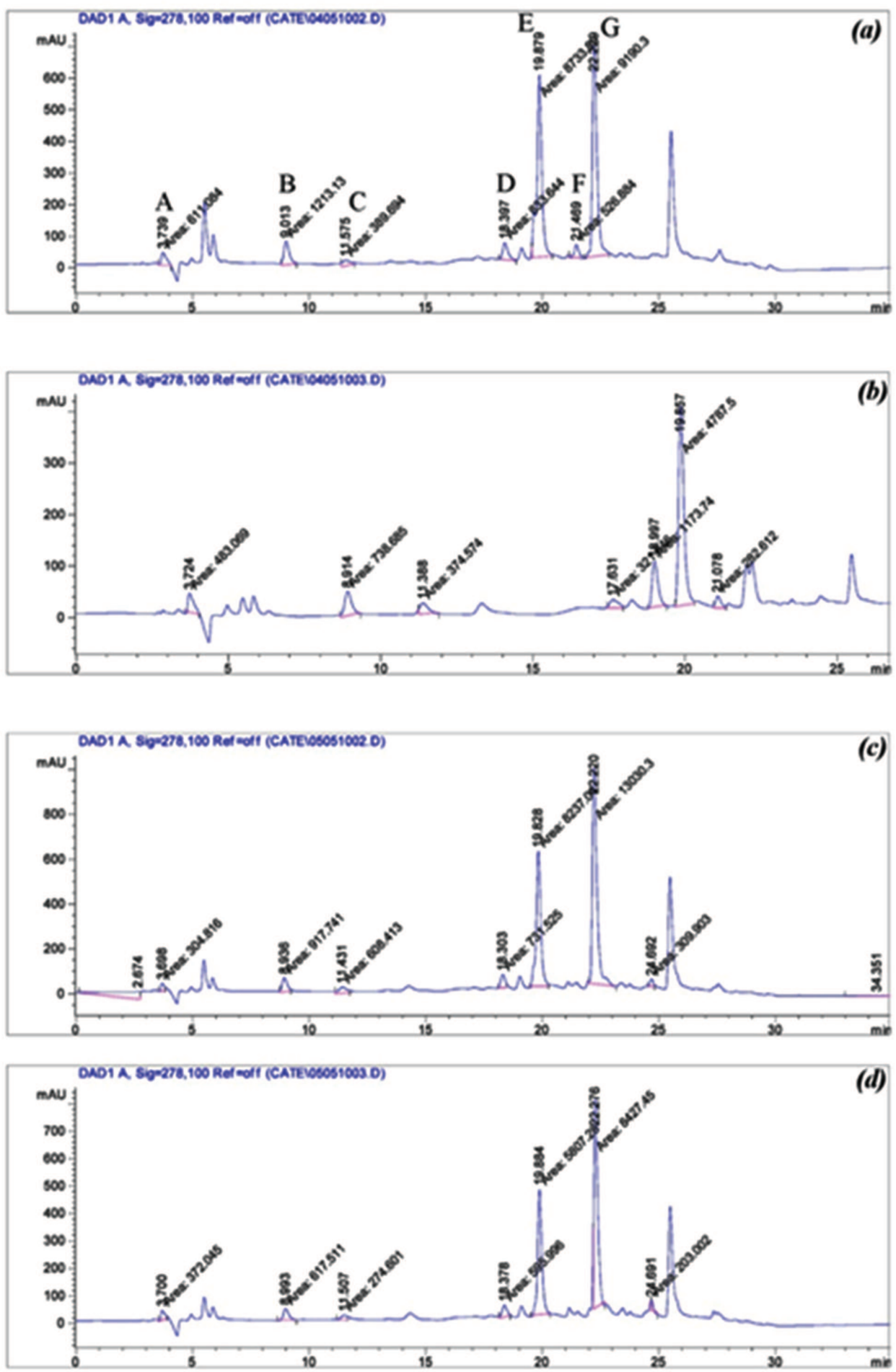

Fig. 1. HPLC chromatogram of catechin fractions in UPASI-16 clone

(a) Bud, (b) first internode, (c) first leaf and (d) second leaf

A: Gallic acid (GC); B: Epigallocatechin (EGC); C: Simple catechin (SC); D: Caffeine; E: Epicatechin (EC); F: Epigallocatechin gallate (EGCG); G: Epicatechin gallate (ECG) 
Ramkumar Samynathan, Chella Perumal Palanisamy, Sudhakar Gandhi et al.

The statistical values were calculated using ANOVA and the data were presented with standard error. The critical difference was noted and significance was determined at $p=0.05$ level (23).

\section{RESULTS AND DISCUSSION}

Morphological selection of superior quality accessions from large tea germplasm is a time consuming and tedious job. In order to overcome this crisis, PPO activity based screening is an ideal tool. PPO is the major factor in determining the quality of tea (24). Hence, in the present study, PPO activity was analyzed on the selected UPASI-16 clone. The physiological characteristics, secondary metabolites and tea enzymes are suitable markers for the selection of superior cultivars from tea germplasm. In addition to the PPO based screening of superior tea quality, the genetic diversity between the divided tea groups was identified by correlating their biochemical markers with molecular markers (25).

The PPO activity of UPASI-16 clone increased/ decreased in the following order; first internode $>$ first leaf $>$ second leaf $>$ bud $>$ third leaf, shown in the Table 1 . The total PPO activity was maximum in first internode $(1178.63 \mathrm{U} / \mathrm{mg}$ of protein) followed by first leaf (1172.81 U/mg of protein) than in other parts (second leaf, bud and third leaf) in UPASI-16. contents of polyphenols and catechins decreased with the increase in maturity of the leave.

The catechin fractions of powdered dried tea leaves from UPASI-16 clone was analyzed by comparing the retention time of the standard compounds under similar chromatographic conditions (26). Seven distinct catechin fractions were identified at different time interval within 30 minutes. Gallic acid appeared at $4^{\text {th }}$ minute followed by epigallocatechin (EGC) at $8^{\text {th }}$ minute, caffeine (CA) at $10^{\text {th }}$ minute, simple catechin at $14^{\text {th }}$ minute, epicatechin (EC) at $16^{\text {th }}$ minute, epigallocatechin gallate (EGCG) at $18^{\text {th }}$ minute and epicatechin gallate (ECG) at $25^{\text {th }}$ minute. From the HPLC analysis, it was evident that caffeine, epigallocatechin gallate (EGCG) and epigallocatechin (EGC) were more predominant (Figure 1).

From the HPLC analysis, significant variation in catechin content was observed in the crop shoots and mature leaves. The major catechin fractions namely, GA, EGC, (+) C, EC, EGCG, ECG and CA were higher in UPASI-16 (Table 2). The decrease in catechin content with the maturity of leaves was reported by Aucamp et al., (2000). In the present study, pharmaceutically important compounds, namely $+\mathrm{C}$, EGCG, and EGC, were much more predominant when compared to other compounds (27).

Table 2. Relative distribution of catechin fractions in UPASI- 16 clone

\begin{tabular}{|c|c|c|c|c|c|c|c|c|}
\hline $\begin{array}{l}\text { Fraction } \\
\text { No. }\end{array}$ & $\begin{array}{l}\text { Catechin } \\
\text { fractions }\end{array}$ & Bud & First leaf & $\begin{array}{c}\text { First } \\
\text { internode }\end{array}$ & $\begin{array}{l}\text { Second } \\
\text { leaf }\end{array}$ & $\begin{array}{c}\text { Third } \\
\text { leaf }\end{array}$ & $\mathrm{SEM} \pm$ & $\begin{array}{c}\text { C.D.@ P } \\
=0.05\end{array}$ \\
\hline 1 & EGC \% & 3.21 & 4.06 & 4.35 & 3.85 & 2.96 & 0.04 & 0.09 \\
\hline 2 & SC $\%$ & 0.88 & 1.19 & 1.49 & 1.00 & 0.84 & 0.03 & 0.07 \\
\hline 3 & EC \% & 1.59 & 2.01 & 2.51 & 1.85 & 1.23 & 0.02 & 0.05 \\
\hline 4 & EGCG \% & 9.25 & 11.96 & 12.05 & 10.21 & 7.35 & 0.08 & 0.17 \\
\hline 5 & ECG \% & 1.87 & 3.19 & 3.26 & 2.47 & 1.81 & 0.04 & 0.08 \\
\hline 6 & TC \% & 16.4 & 22.46 & 23.66 & 19.38 & 14.61 & 0.14 & 0.31 \\
\hline
\end{tabular}

EGC - epigallocatechin, SC - simple catechin, EC - epicatechin, EGCG - epicatechin gallate, ECG - epicatechin gallate and TC - total catechin. SEM - Standard Error Mean. C.D.- Critical difference

The total polyphenol and catechin contents were similar in the following order, first internode $>$ first leaf $>$ second leaf $>$ bud $>$ third leaf. Polyphenol content in UPASI-16 ranged from $31.70 \%$ to $27.38 \%$ and that of $\mathrm{P} / 11 / 15$ from $20.01 \%$ to $17.97 \%$. The catechin content ranged from $15.87 \%$ to $22.88 \%$ in UPASI-16 and $13.59 \%$ to $20.75 \%$ in $\mathrm{P} / 11 / 15$ (Table 1 ). The
Peroxidase helps in the conversion of Theaflavins (TF) to Thearubigins (TR) by utilizing $\mathrm{H}_{2} \mathrm{O}_{2}$ as an electron acceptor using catechin as a substrate (28). The peroxidase activity increased/decreased in the following order: first internode $>$ bud $>$ first leaf $>$ second leaf $>$ third leaf (Table 1). Peroxidase activ- 
ity was maximum in the first internode $(729.72 \mu \mathrm{M}$ of $\mathrm{O}_{2}$ formed $\min ^{-1} \mathrm{~g}^{-1}$ dry weight) followed by bud (727.00 $\mu \mathrm{M}$ of $\mathrm{O}_{2}$ formed $\mathrm{min}^{-1} \mathrm{~g}^{-1}$ dry weight) than the other parts (first leaf, second leaf and third leaf) in UPASI-16. First internode and bud showed high peroxidase activity which might be due to high accumulation of theaflavins.

Catalase is a primary $\mathrm{H}_{2} \mathrm{O}_{2}$ scavenger in the peroxisomes and mitochondria (29). Catalase activity was highest in the first internode followed by bud and leaves. Catalase activity of UPASI-16 ranged between 0.99 and $1.89 \mu \mathrm{M} \mathrm{H}_{2} \mathrm{O}_{2}$ reduced $\mathrm{min}^{-1} \mathrm{mg}^{-1}$ protein (Table1).

In UPASI-16, SOD activity varied from 39.44 to $58.45 \mathrm{U} / \mathrm{mg}$. In addition, the first internode and bud showed relatively higher activity followed by leaves in both accessions (Table 1). PAL activity decreased from bud to third leaf in both selected accession of UPASI-16 (Table 1). The enzyme activity ranged from 13.85 to $38.40 \mathrm{mM}$ when compared with cinnamic acid formed per minute. However, a decreased PAL activity was observed in the bud, followed by first internode, first leaf, second and third leaves. The reason for the increased PAL and SOD activity in the bud of UPASI-16 might be due to genetic nature ability of the plant to withstand drought conditions. Upregulation of SOD and PAL activity under drought conditions were reported.

PPO of the tea plant exists in multiple forms which further comprises the number of subunits. The protein profile (number and intensity of bands) of UPASI-16 based on PPO activity on 12\% SDSPAGE and its analysis revealed more than forty two protein bands in UPASI-16 with molecular weight ranging from 19.5 to $213 \mathrm{kDa}$. Variations in the intensity of protein were observed in the range of 15 to $20 \mathrm{kDa}$ and 30 to $40 \mathrm{kDa}$ (Figure 2). The absence or less intense protein bands reflects low expression of the corresponding protein.

Total RNA was isolated from the bud of UPASI-16. Two distinct bands for $18 \mathrm{~S}$ and $28 \mathrm{~S}$ were observed (Figure 3). The $\mathrm{A}_{260 / 280}$ ratio was 1.8 - 2.0. The expression of flavonoid genes viz., ANR, F3H, F35H and ANS in the segregated crop shoot (bud, first internode, first leaf and second leaf) of selected accession of UPASI - 16 clone was revealed by semi quantitative RT-PCR. The $26 \mathrm{~S}$ rRNA gene was used as a ref-

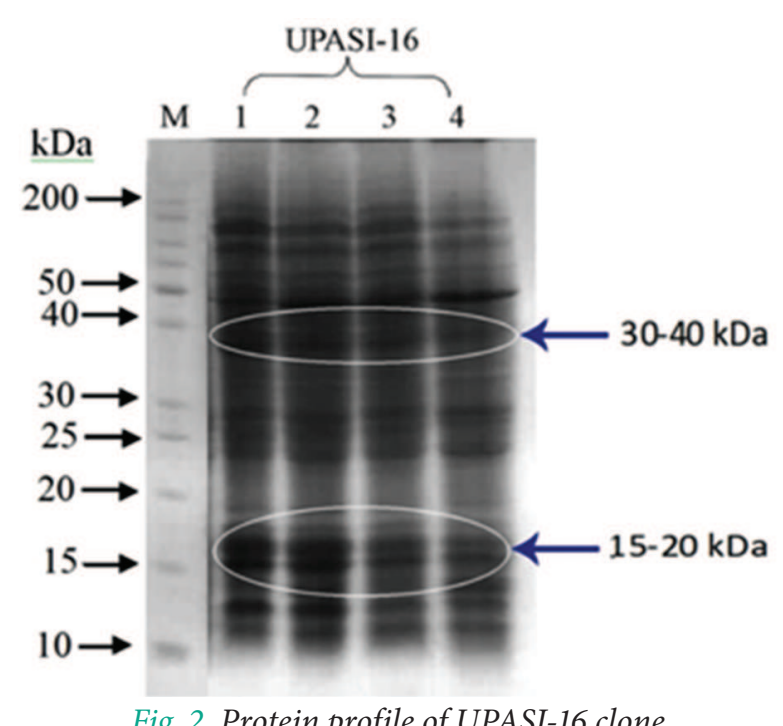

Fig. 2. Protein profile of UPASI-16 clone

Lane M - Marker, 1 - Bud, Lane 2 - first Internode, Lane 3 first Leaf, Lane 4 - second Leaf

erence to analyze the cDNA that were preferentially expressed in the segregated samples. Amplification was efficient with $50 \mathrm{ng} \mathrm{mL}^{-1}$ of total RNA in all parts of the shoots. Higher expression of $\mathrm{F} 35 \mathrm{H}$ was observed in the bud of UPASI 16 (1.13\%) followed by first internode, first leaf and second leaf. A similar pattern was observed in the rest of the flavonoid gene expression (bud $>$ first internode $>$ first leaf $>$ second leaf). Among the expression of all the genes, the expression of ANS was higher when compared to other flavonoid genes in the bud of UPASI $16(2.82 \%)$ (Table 3 and Figure. 3).

Flavonoid pathway was noticed in Camellia sinensis, the expression of $\mathrm{F} 3 \mathrm{H}$ gene was the highest

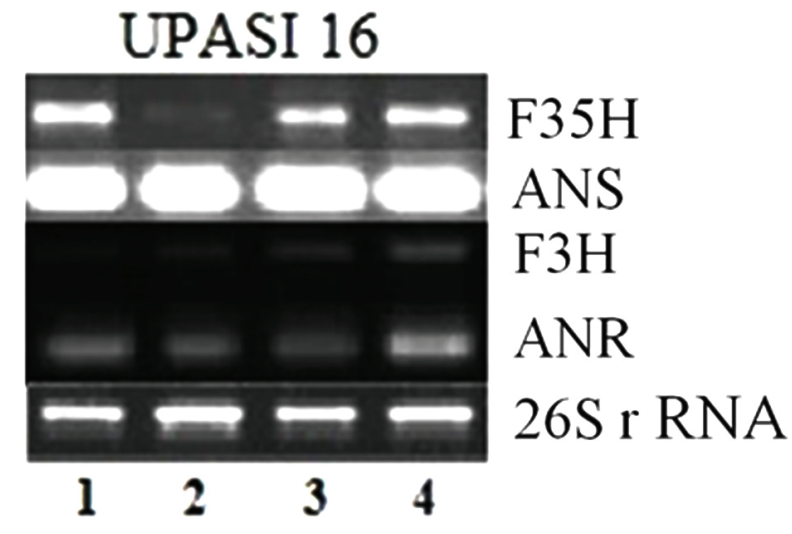

Fig. 3. Flavonoid gene expression in UPASI-16 clone Lane: 1 - Bud, 2 - First internode, 3 - First leaf, 4 - Second leaf 
Ramkumar Samynathan, Chella Perumal Palanisamy, Sudhakar Gandhi et al.

\begin{tabular}{|c|c|c|c|c|}
\hline Gene & Bud & $\begin{array}{c}\text { First } \\
\text { internode }\end{array}$ & $\begin{array}{l}\text { First } \\
\text { leaf }\end{array}$ & $\begin{array}{c}\text { Second } \\
\text { leaf }\end{array}$ \\
\hline $\mathrm{F} 35 \mathrm{H}$ & 1.13 & 0.95 & 0.75 & 0.10 \\
\hline ANS & 2.82 & 2.67 & 2.60 & 2.57 \\
\hline $\mathrm{F} 3 \mathrm{H}$ & 0.94 & 0.48 & 0.31 & 0.20 \\
\hline ANR & 1.47 & 0.98 & 0.73 & 0.60 \\
\hline $\begin{array}{l}26 \mathrm{~S} \\
\text { rRNA }\end{array}$ & 1.00 & 1.00 & 1.00 & 1.00 \\
\hline
\end{tabular}

in leaves. However, their accumulation, especially F3H level, was very low and had undetectable levels in mature leaves. High expression of ANR in leaves and stems may be closely related to high epigallocatechin and epicatechin synthesis in these organs (30).

\section{CONCLUSION}

The distribution of biochemical contents of catechin and polyphenol in crop shoots followed in the order of: first internode $>$ first leaf $>$ second leaf $>$ bud $>$ third leaf of the selected UPASI-16 clone, in which the first internode registered higher amount of catechin followed by bud, first leaf and second leaf. In SDS-PAGE analysis, UPASI-16 accession showed variation in the intensity of protein bands between 15 to $20 \mathrm{kDa}$ and 30 to $40 \mathrm{kDa}$. In this study, the PPO enzyme was useful in the identification of potential biomarkers and engineering the flavonoid pathway related gene up-regulation ( $\mathrm{F} 35 \mathrm{H}$ and ANS). These results will be further used for screening superior accessions from germplasm.

\section{ACKNOWLEDGMENTS}

We are grateful to Dr. B.Radhakrishan, Director and Dr. R.Rajkumar, Senior Plant physiologist, UPASI Tea Research Institute for their helpful suggestions and technical advice in this study.

\section{REFERENCES}

1. Yamamoto T, Juneja LR, Chu DC, Kim M. (Eds). Chemistry and Application of Green Tea. New York: CRC Press; 1998.

2. Rogers PJ, Smith JE, Heatherley SV, Pleydell-Pearce CW. Time for tea: mood, blood pressure and cognitive performance effects of caffeine and theanine administered alone and together. Psychopharmacology. 2008;195:569-577.

3. Park JS, Kim JB, Hahn BS, Kim KH, Ha SH, Kim $\mathrm{YH}$. EST analysis of genes involved in secondary metabolism in Camellia sinensis (tea), using suppression subtractive hybridization. Plant Sci. 2004;166:953-961.

4. Chen L, Zhao LP, Gao QK. Generation and analysis of expressed sequence tags from the tender shoots cDNA library of tea plant (Camellia sinensis). Plant Sci. 2005;168:359-363.

5. Richelle M, Tavazzi I, Offord E. Comparison of the antioxidant activity of commonly consumed polyphenolic beverages (coffee, cocoa, and tea) prepared per cup serving. J Agric Food Chem. 2001;49:3438-3442.

6. Starlin T, Ragavendran P, Raj CA, Perumal PC, Gopalakrishnan VK. Element and functional group analysis of Ichnocarpus frutescens R. Br. (Apocynaceae). Int J Pharm Pharm Sci. 2012;4:343-345.

7. Perumal PC, Sophia D, Raj CA, Ragavendran P, Starlin T, Gopalakrishnan VK. In vitro antioxidant activities and HPTLC analysis of ethanolic extract of Cayratia trifolia (L.). Asian Pac J Trop Dis. 2012;2:S952-S956.

8. Poornima K, Perumal PC, Gopalakrishnan VK. Protective effect of ethanolic extract of Tabernaemontana divaricata (L.) R. Br. against DEN and Fe NTA induced liver necrosis in Wistar Albino rats. Biomed Res Int. 2014;2014:240243.

9. Perumal PC, Sowmya S, Pratibha P, Vidya B, Anusooriya $\mathrm{P}$, Starlin T, et al., Identification of novel PPAR $\gamma$ agonist from GC-MS analysis of ethanolic extract of Cayratia trifolia (L.): a computational molecular simulation studies. J App Pharm Sci. 2014;4:006-011.

10. Pratibha P, Sophia D, Perumal PC, Gopalakrishnan VK. In-silico docking analysis of Emilia sonchifolia (1.) dc. gas chromatography-mass spectroscopy derived terpenoid compounds against pancreatic cancer targets (AKT and BRCA2). World J Pharm Pharm Sci. 2014;3:1844-1855.

11. Perumal PC, Sowmya S, Pratibha P, Vidya B, Anusooriya P, Starlin T, et al. Isolation, structural characterization and in silico drug-like properties prediction of bioactive compound from ethanolic extract of Cayratia trifolia (L.). Pharmacog Res. 2015;7:121-125. 
12. Cabrera C, Artacho R, Gimenez R. Beneficial effects of green tea - a review. J Am Col Nutr. 2006;25:79-99.

13. Topalova T, Jelev I, Georgieva S. Quantitative determination of methylxanthines and polyphenols in plant substances. Manage Educat. 2013;9(5):110-114.

14. Ramkumar S, Sureshkumar P, Mandal AKA, Rajaram K, Mohankumar P. Identification of superior varieties of tea (Camellia sinensis (1.) o. kuntze) in the selected UPASI germplasm using biomarkers. Int J Phys Sci. 2011;6(5):727-743.

15. Rawat $\mathrm{R}$, Gulati A. Seasonal and clonal variations in some major glycosidic bound volatiles in Kangra tea (Camellia sinensis (L.) O. Kuntze). European Food Res Technol. 2008;226(6):1241-1249.

16. Bradford MM. A rapid and sensitive method for the quantification of microgram quantities of proteins using the principle of protein-dye -binding. Analytical Biochem. 1976;72:248-254.

17. Dev-Choudhury MN, Goswami MR. A rapid method for the estimation of total polyphenolic matters in tea Camellia sinensis L. Two Bud. 1983;30:59-61.

18. Swain T, Hillis WE. The phenolic constituents of Prunus domestica L.-The quantitative analysis of phenolic constituents. J Sci Food Agric. 1959;10:63-68.

19. Chance B, Maehly AC. Assay of catalase and peroxidases. Methods Enzymol. 1955;2:764-775.

20. Luck H. In: methods in enzymatic analysis. 2nd Ed. New York: Bergmeyer Academic Press; 1974.

21. Van-Rossun MWPC, Alberda M, Van-Derplas LHW. Role of oxidative damage in tulip bulb scale micro propagation. Plant Sci. 1997;130:207-221.

22. Jain, Arun K, Acito F, Malhotra NK, Mahajan V. A Comparison of the Internal Validity of Alternative Parameter Estimation Methods in Decompositional Multiattribute Preference Models. J Mark Res. 1979;16:313-322.

23. Gomez KA, Gomez AA. Statistical procedures for agricultural research with emphasis of rice. Int Rice Res Ins, Los Banos, Philippines; 1976.

24. Sealy J. Species of Camellia in cultivation. R Hort Soc. 1937;62:352-369.

25. Satyanarayana N, Sharma VS. UPASI Biclonal Seed Stocks, Proceedings of the Sixth Joint Area Scien- tific Symposium (JASSVI). UPASI Tea Res Ins Bulletin. 1993;46:144-154.

26. Balasaravanan T, Pius PK, Kumar RR, Muraleedharan N, Shasany AK. Genetic diversity among south Indian tea germplasm (Camellia sinensis, $C$. assamica and C. assamica spp. lasiocalyx) using AFLP markers. Plant Sci. 2003;165:365-372.

27. Jayaganesh $S$, Venkatesan S. Impact of Magnesium Sulphate on Biochemical and Quality Constituents of Black Tea. American J Food Tech. 2010;5:31-39.

28. Collakova E, Klumas C, Suren H, Myers E, Heath LS, Holliday JA, et al. Evidence for extensive heterotrophic metabolism, antioxidant action and associated regulatory events during winter hardening in Sitka spruce. BMC Plant Biol. 2013;13(72):1-16.

29. Kerdnaimongkol K, Woodson WR. Inhibition of Catalase by Antisense RNA Increases Susceptibility to Oxidative Stress and Chilling Injury in Transgenic Tomato Plants. J American Soc Hort Sci. 1999;124(4):330-336.

30. Punyasiri P, Abeysinghe IS, Kumar V, Treutter D, Duy D, Gosch C, et al. Flavonoid biosynthesis in the tea plant Camellia sinensis: properties of enzymes of the prominent epicatechin and catechin pathways. Arch Biochem Biophys. 2004;431:22-30. 